assist him in completing this collection and states that he will be glad to supply lists of the species still unrepresented.

\section{Royal Society of Medicine of Ghent}

THE centenary of the foundation of the Royal Society of Medicine of Ghent was celebrated on May 26 in the presence of some three hundred medical men from all parts of Belgium and France under the presidency of Dr. Van Cauwenberghe. The inaugural meeting, in which the history of the Society was related by the secretary, M. de Bersaques, was followed by a scientific gathering at which papers were read by Profs. Leriche of Strasbourg, Polak Daniels of Gröningen and Dr. Ragin of Lausanne.

\section{Announcements}

WE much regret to announce the death, at the age of seventy-nine years, of Dr. L. Cockayne, F.R.S., honorary botanist of the State Forest Service of New Zealand; and also of Dr. N. L. Britton, emeritus director of the New York Botanic Garden, on June 25, at the age of seventy-five years.

The Rogers Field Gold Medal of the Royal Sanitary Institute has been awarded to Imperial Chemical Industries Ltd., for an exhibit of Chloros at the Bristol Congress of the Institute just concluding. The medal is given for an exhibit of outstanding merit from the point of view of hygiene. The special features of the Chloros exhibit at Bristol were its uses in connexion with the sterilisation of rural water supplies and swimming pools.

ThE Secretary of State for the Colonies has ap. pointed Mr. A. C. Miles, provincial superintendent of agriculture, to be deputy director of agriculture, Gold Coast.

DR. R. C. Bowden, chemical engineer under the Director of Ordnance Factories, has been appointed by the War Office to be Superintendent, Royal Gunpowder Factory, Waltham Abbey, in succession to Lieut.-Col. P. H. Evans, Royal Artillery, who retires on July 12 .

THE trustees of the Bernhard Baron Charitable Trust have made a grant of $£ 10,000$ to the British Empire Cancer Campaign in response to its Empire Day appeal. The money will be put in a special fund to be called the "Bernhard Baron Cancer Fund".

THE annual Autumn Meeting of the Institute of Metals will be held at Manchester on September 3-6, under the chairmanship of Dr. Harold Moore, president of the Institute. On September 3, Dr. J. L. Haughton will deliver the thirteenth Autumn Lecture entitled: "The Work of Walter Rosenhain". Further information can be obtained from the secretary of the Institute, 36 Victoria Street, London, S.W.1.

IN 1920, Miss L. Jones-Bateman, of Cae Glass, Abergele, presented to the Royal Horticultural
Society a valuable silver-gilt replica of the Warwick vase to be used for the encouragement of fruit production. It has accordingly been decided to offer it triennially for researches in the growing of hardy fruits, figs, grapes and peaches in the open or under glass, and it is available for award in 1934. Candidates should submit accounts of their work by October 31. The work dealt with must have been carried out by the candidate in the United Kingdom mainly during the past five years.

Messrs. Longmans, Green and Co., Ltd. announce for publication in September a work by Mr. G. C. Robson, deputy keeper of zoology at the British Museum (Natural History), and Mr. O. W. Richards, lecturer in entomology at the Imperial College of Science and Technology, entitled "Variations of Animals in Nature". In this work the authors have summarised the evidence on the subject in an attempt to decide what evolutionary theory is in best agreement with the facts.

Applicatrons are invited for the following appoint. ments, on or before the dates mentioned :-A parttime assistant in statisties at the London School of Economics and Political Science, Houghton Street, Aldwych, W.C.2-The Secretary (July 17). An assistant lecturer in electrical engineering at the York Technical Institute-The Secretary for Education, Education Offices, Clifford Street, York (July 18). An assistant lecturer in the Department of Zoology, preferably a vertebrate morphologist, at University College, London, W.C.I-The Secretary (July 18). A head of the Department of Geology, Mineralogy and Geography at the Chelsea Polytechnic, London, S.W.3-The Principal (July 21). A lecturer (man) to take charge of the Post-Graduate Training Department of University College, Leicester-The Registrar (July 21). A lecturer in engineering at the Denbighshire Technical Institute, Wrexham-The Principal (July 21). A teacher of engineering at Leigh Municipal College The Director of Education, Town Hall, Leigh (July 21). An assistant lecturer in geography at University College, Exeter-The Registrar (July 28). A deputy director and bacteriologist at Adelaide Hospital, who will also be lecturer in bacteriology in the University-The Agent General for South Australia, Australia House, Strand, London, W.C.2 (Aug. 15). A biochemist or chemist, preferably with knowledge of physical chemistry and biology, for an investigation into the effect of oil upon mosquito larvæ, at the London School of Hygiene and Tropical Medicine, Keppel Street, W.C.1-The Secretary (Sept. 7). A professor of mathematics in Victoria University College, Wellington, New Zealand-The Secretary, Universities Bureau of the British Empire, 88a, Gower Street, London, W.C.1. Demonstrators in mechanical engineering, electrical engineering and communications, and physics, at Woolwich Poly. technic, London, S.E.18-The Secretary. A teacher of mining and engineering in East Kent-The Acting Principal, Technical Institute, Ladywell, Dover. 